\title{
Effect of Recombinant Bovine Somatotropin (rbST) on Cytoplasmic Maturation of Bovine Oocytes and Their Developmental Competence In Vitro
}

\author{
Tatjana I. KUZMINA ${ }^{1)}$, Hannelore ALM ${ }^{2)}$, Vitaly DENISENKO'), \\ Armin TUCHSCHERER ${ }^{2)}$, Wilhelm KANITZ ${ }^{2)}$ and Helmut TORNER ${ }^{2)}$ \\ 1)All-Russian Research Institute for Farm Animal Genetics and Breeding, 189620 St. \\ Petersburg-Pushkin, Russia and ${ }^{2)} F B N$ Research Institute for the Biology of Farm Animals, \\ Wilhelm-Stahl-Allee 2, 18196 Dummerstorf, Germany
}

\begin{abstract}
The objectives of this study were to evaluate the effects of recombinant bovine somatotropin (rbST) on the nuclear and cytoplasmic maturation of bovine oocytes and their further developmental competence to blastocysts in vitro. We analyzed the mitochondrial activity and concentration of intracellular stored calcium $\left(\left[\mathrm{Ca}^{2+}\right]_{\text {is }}\right)$ in matured oocytes and the morphology and chromatin status of produced embryos after in vitro fertilization. Cumulus-oocyte complexes were incubated in TCM 199 containing $10 \%$ fetal calf serum (control medium 1: CM 1) or $10 \%$ estrus cow serum (control medium 2: CM 2). The culture medium of the treatment groups was modified by supplementation of the control medium with $10 \mathrm{ng} / \mathrm{ml} \mathrm{rbST} \mathrm{(CM} 1 \mathrm{~A}$ and CM 2A), $10^{6} / \mathrm{ml}$ granulosa cells (CM $1 \mathrm{~B}$ and CM 2B), or $10 \mathrm{ng} / \mathrm{ml} \mathrm{rbST}$ plus $10^{6} / \mathrm{ml}$ granulosa cells (CM 1C and CM 2C). No differences were observed in the percentages of oocytes reaching metaphase II between the groups. However, the proportion of blastocysts was highest in treatment groups $\mathrm{CM} 1 \mathrm{C}$ and $\mathrm{CM} 2 \mathrm{C}(\mathrm{P}<0.05)$. The type of serum did not alter the positive effect of rbST on the developmental competence of embryos. The fluorescence intensity of metabolically active mitochondria measured by intensity per oocyte (Em 570) after MitoTracker CMTM Ros Orange labeling was significantly increased in oocytes matured in the presence of $10 \mathrm{ng} / \mathrm{ml} \mathrm{rbST}$ and granulosa cells (309.21 vs. $119.97 \mu \mathrm{A} ; \mathrm{P}<0.01)$. In parallel, the concentration of $\left[\mathrm{Ca}^{2+}\right]_{\text {is }}$ in oocytes, determined using fluorophore chlortetracycline, was significantly decreased $(0.85 \pm 0.02$ vs. $0.97 \pm 0.03 \mathrm{AU} ; \mathrm{P}<0.05)$. Based on these results, we concluded that $\mathrm{rbST}$, in interaction with granulosa cells stimulates the oxidative activity of ooplasmic mitochondria and decreases the content of $\left[\mathrm{Ca}^{2+}\right]_{\text {is }}$ in oocytes. These facts support the hypothesis that somatotropin influences the developmental competence of bovine oocytes during maturation in vitro, and this effect can be modulated by granulosa cells.

Key words: Bovine, Calcium, Embryo, Mitochondrial activity, Oocyte maturation, Recombinant bovine somatotropin (rbST)
\end{abstract}

(J. Reprod. Dev. 53: 309-316, 2007)

$\mathbf{A}$ considerable amount of literature has been published on the possibility of using in vitro maturation (IVM) and in vitro fertilization (IVF)

Accepted for publication: October 30, 2006

Published online: December 1, 2006

Correspondence: $\mathrm{H}$. Torner

(e-mail: torner@fbn-dummerstorf.de) technologies for the aims of embryo transfer and cell and genetic engineering [1]. Basic research on oocyte maturation would provide a source of high quality oocytes for reproductive cell technologies and benefit the commercial embryo transfer industry. Embryo development is strongly 
influenced by events occurring during oocyte maturation. The developmental potential of bovine oocytes is related to many factors, such as the morphology of cumulus-oocyte complexes, the diameter of follicles, and the culture system [2]. One important factor in the complex of fertility events is the growth hormone, somatotropin (ST) $[3,4]$, which influences the regulation of growth and differentiation of various cell types and control of the metabolic activity of organs and tissues. Addition of ST during IVM of bovine cumulusoocyte complexes accelerates nuclear maturation, induces cumulus expansion, and promotes subsequent embryonic development [5]. Izadyar et al. [6] showed that supplementation with 100 and $1,000 \mathrm{ng} / \mathrm{ml} \mathrm{ST}$ during maturation in vitro significantly enhanced subsequent cleavage rate and embryonic development. Growth hormones (GHs) like ST during IVM increase cumulus expansion by promotion of cell proliferation and inhibition of apoptosis [7]. It has also been found that bovine cumulus cells, mural granulosa, and oocytes express mRNA for growth hormone receptor (GHR), but the stimulatory effect of $\mathrm{GH}$ on bovine oocyte maturation is dependent on cumulus cells and is not mediated by insulin-like growth factor (IGF)-I [8]. GH supplementation during IVM enhances the migration of cortical granules and sperm aster formation [6], leading previous researchers to conclude that the promotory effect of $\mathrm{GH}$ on the developmental competence of the oocyte is due to a higher fertilization rate as a consequence of improved cytoplasmic maturation.

The cytoplasm of the oocyte may play a crucial role in assembling the correct metabolic machinery for production of sufficient energy for cellular function during maturation, cleavage, and blastocyst formation. Development of organelleand ion-specific probes now permits studies of compartmentalization and spatial organization within the oocyte and embryo. Reorganization of mitochondria and changes in their activity during maturation are important parameters for oocyte cytoplasmic maturation [9, 10]. Mitochondria provide energy for the intensive metabolism of oocytes during final maturation [11]. Oocyte apoptosis is influenced by alterations in the biochemical and ultrastructural properties of mitochondria [12]. Van Blerkom et al. [13] proposed that high-polarized pericortical mitochondria may have a function in the acquisition of oocyte competence and in the regulation of early developmental processes. This may be associated with elevated metabolism or intracellular signalling through calcium-induced calcium release pathways. Calcium is an important intracellular messenger, and calcium ions regulate many key intracellular events. Because mitochondria synthesize ATP and serve as an internal source of $\mathrm{Ca}^{2+}$, it is possible that mitochondria redistribute and aggregate within the oocyte to concentrate ATP and $\mathrm{Ca}^{2+}$ at sites of high demand $[14,15]$.

To explain the stimulatory effect of ST on oocyte maturation, we focused our interest on the alterations of mitochondrial activity and $\mathrm{Ca}^{2+}$ concentration. A better understanding of the metabolic characteristics of oocytes matured in the presence of rbST and the consequence of alterations in these parameters on developmental competence is needed and could give an answer to the question regarding which mechanisms are involved in the stimulation effect of ST on maturation of oocytes. Therefore, the aims of the present study were to (i) determine the influence of recombinant bovine ST (rbST) on the developmental competence of bovine oocytes (experiment 1), (ii) determine the influence of rbST on the ongoing embryonic quality of oocytes on days 2 and 5 (experiment 2), and (iii) evaluate the effects of rbST on the cytoplasmic quality of oocytes after IVM (experiment 3).

\section{Materials and Methods}

Recovery of oocytes and preparation of granulosa cells

Ovaries from dairy cows were obtained at a slaughterhouse and transported within $2 \mathrm{~h}$ to the laboratory in sterile PBS maintained at 35 to $37 \mathrm{C}$. The cumulus-oocyte complexes (COCs) were recovered by slicing the surfaces of ovaries. The oocytes were collected in TCM 199 with $10 \%$ fetal calf serum (FCS). Only oocytes having complete, compact, multilayered cumulus and homogeneous ooplasm were used for culture. Before cultivation, the oocytes were washed twice in TCM 199 with $10 \%$ FCS.

Granulosa cells (GC) were collected from the medium from which COCs were dissected from follicles ( 3 to $5 \mathrm{~mm}$ in diameter) and centrifuged twice for $5 \mathrm{~min}$ at $500 \mathrm{~g}$. The final pellet of granulosa cells was resuspended in maturation 
medium. Co-culture of oocytes and granulosa cells was carried out in Petri dishes in $2 \mathrm{ml}$ of medium at $38.5 \mathrm{C}$ in an atmosphere of $5 \% \mathrm{CO}_{2}$ for $24 \mathrm{~h}$.

\section{Oocyte maturation}

Selected COCs were matured for $24 \mathrm{~h}$ at $38.5 \mathrm{C}$ in different treatment groups based on following culture systems.

Control medium 1 (CM 1) contained TCM 199 with Earle's salts, L-glutamine, 25 mM HEPES supplemented with $10 \%$ (v/v) heat-treated FCS, and trace amounts of antibiotics (50 IU/ml penicillin and $50 \mu \mathrm{g} / \mathrm{ml}$ streptomycin).

CM $1+\operatorname{rbST}($ CM 1A) contained TCM 199 with Earle's salts, L-glutamine, 25 mM HEPES supplemented with $10 \%(\mathrm{v} / \mathrm{v})$ heat-treated FCS, trace amounts of antibiotics (50 $\mathrm{IU} / \mathrm{ml}$ penicillin and $50 \mu \mathrm{g} / \mathrm{ml}$ streptomycin), and $10 \mathrm{ng} / \mathrm{ml} \mathrm{rbST}$.

CM 1 + GC (CM 1B) contained TCM 199 with Earle's salts, L-glutamine, 25 mM HEPES supplemented with $10 \%(\mathrm{v} / \mathrm{v})$ heat-treated FCS, trace amounts of antibiotics (50 IU $/ \mathrm{ml}$ penicillin, 50 $\mu \mathrm{g} / \mathrm{ml}$ streptomycin), and $1 \times 10^{6} / \mathrm{ml}$ granulosa cells.

CM $1+$ rbST + GC (CM 1C) contained TCM 199 with Earle's salts, L-glutamine, 25 mM HEPES supplemented with $10 \%(\mathrm{v} / \mathrm{v})$ heat-treated FCS, trace amounts of antibiotics (50 $\mathrm{IU} / \mathrm{ml}$ penicillin and $50 \mu \mathrm{g} / \mathrm{ml}$ streptomycin), $10 \mathrm{ng} / \mathrm{ml} \mathrm{rbST}$ and 1 $\times 10^{6} / \mathrm{ml}$ granulosa cells.

Control medium 2 (CM 2) contained TCM 199 with Earle's salts, L-glutamine, 25 mM HEPES supplemented with $10 \%(\mathrm{v} / \mathrm{v})$ heat-treated ECS (estrous cow serum), and trace amounts of antibiotics (50 IU/ml penicillin and $50 \mu \mathrm{g} / \mathrm{ml}$ streptomycin).

CM $2+\operatorname{rbST}($ CM 2A) contained TCM 199 with Earle's salts, L-glutamine, 25 mM HEPES supplemented with $10 \%(\mathrm{v} / \mathrm{v})$ heat-treated ECS, trace amounts of antibiotics $(50 \mathrm{IU} / \mathrm{ml}$ penicillin and $50 \mu \mathrm{g} / \mathrm{ml}$ streptomycin) and $10 \mathrm{ng} / \mathrm{ml} \mathrm{rbST}$.

CM 2 + GC (CM 2B) contained TCM 199 with Earle's salts, L-glutamine, 25 mM HEPES supplemented with $10 \%(\mathrm{v} / \mathrm{v})$ heat-treated ECS, trace amounts of antibiotics $(50 \mathrm{IU} / \mathrm{ml}$ penicillin and $50 \mu \mathrm{g} / \mathrm{ml}$ streptomycin), and $1 \times 10^{6} / \mathrm{ml}$ granulosa cells.

CM 2 + rbST + GC (CM 2C) contained TCM 199 with Earle's salts, L-glutamine, 25 mM HEPES supplemented with $10 \%(\mathrm{v} / \mathrm{v})$ heat-treated ECS, trace amounts of antibiotics $(50 \mathrm{IU} / \mathrm{ml}$ penicillin and $50 \mu \mathrm{g} / \mathrm{ml}$ streptomycin), $1 \times 10^{6} / \mathrm{ml}$ granulosa cells and $10 \mathrm{ng} / \mathrm{ml} \mathrm{rbST}$.

The concentration of rbST used during IVM (10 $\mathrm{ng} / \mathrm{ml}$ ) was found to produce the optimal blastocyst rate in previous studies in which we compared 5, 10, 50 and $100 \mathrm{ng} / \mathrm{ml} \mathrm{rbST}$ (unpublished data). All maturation media were adjusted to $\mathrm{pH}$ 7.3.

\section{In vitro fertilization and subsequent embryo culture in vitro}

After IVM, oocytes were partially denuded by gentle pipetting to remove the loosely attached expanded cumulus cells and were transferred in groups of 5 oocytes to fertilization droplets. Fertilization was carried out in $46 \mu \mathrm{l}$ microdroplets of modified Tyrode's medium. A volume of 2 to 5 $\mu \mathrm{l}$ of the sperm suspension was added to each fertilization droplet to give a final concentration of approximately 1.0 to $1.5 \times 10^{6}$ motile sperm $/ \mathrm{ml}$. Fertilization was carried out for $24 \mathrm{~h}$ at $38.5 \mathrm{C}$ under $5 \% \mathrm{CO}_{2}$ in $100 \%$ humidified air.

\section{Evaluation of oocytes and embryos}

Nuclear maturation of the oocytes was evaluated using the cytogenetic method described by Tarkowski [16]. Oocytes matured over $24 \mathrm{~h}$ were placed in $0.9 \%$ sodium citrate in water for $10 \mathrm{~min}$, stripped free of cumulus cells using a dissecting needle, fixed in methanol-acetic acid (3:1), stained with $5 \%$ Giemsa solution for $10 \mathrm{~min}$ at room temperature, and examined under a light microscope at $\times 900$ magnification for determination of nuclear status. The procedure to estimate the chromatin status of embryos on day 2 (2- to 4-cell stages) and day 5 (morulae) was the same as described for oocytes; however, before analysis, the embryos were also incubated in $0.1 \%$ hyaluronidase for $20 \mathrm{~min}$. Embryos with bi- or multinuclear blastomeres, blastomeres including pycnotic chromatin, and blastomeres without chromatin were classified as not intact.

\section{Intracellular stored calcium $\left[\mathrm{Ca}^{2+}\right]_{\text {is }}$ assay}

The levels of $\left[\mathrm{Ca}^{2+}\right]_{\text {is }}$ in the oocytes were estimated on the basis of previously described measurements of the fluorescence intensity of calciumchlortetracycline (CTC) complexes on irradiation $[17,18]$. The fluorescence intensity was recorded under a luminescent microscope (LUMAM-I-1, LOMO, St. Petersburg, Russia) equipped with a 
special photoelectronic multiplier (FEU-39A), an excitation filter (FS1; 6-mm thick), a green analysis filter, an interference light filter (passing maximum wavelength of $520 \mathrm{~nm}$ ), and a mercury lamp. The excitation wavelength was 380 to $400 \mathrm{~nm}$, and the emission wavelength was $520 \mathrm{~nm}(\mathrm{slit}=10 \mathrm{~nm})$. Measurement was performed within 10 sec. Chlortetracycline solutions were prepared in saline (150 mM NaCl, pH 7.0) immediately prior to the experiments. The oocytes were placed in special quartz wells with saline containing $40 \mu \mathrm{M} \mathrm{CTC}$ and were incubated for $5 \mathrm{~min}$ in a water bath $(37 \mathrm{C})$. The diameter of the probe used was constant $(1 \mathrm{~mm})$, and the diameter of the areas assayed was $100 \mu \mathrm{m}$. Irradiation was focused at the center of the oocytes, and the intensity of cell fluorescence was measured as an electric signal. The values of the background emission were subtracted from the obtained magnitudes. The levels of $\left[\mathrm{Ca}^{2+}\right]$ is were expressed in arbitrary units (AU) of the intensity of oocyte fluorescence.

\section{Fluorescence labelling of mitochondria and measurement of fluorescence intensity}

The in vitro matured COCs were incubated for 30 min in PBS containing 3\% bovine serum albumin (BSA) and $200 \mathrm{nM}$ MitoTracker Orange CMTM Ros (Molecular Probes, Eugene, OR, USA) under culture conditions [10]. Cell-permeant MitoTracker Orange-fluorescent tetramethylrosamine (M-7510) probe is readily sequestered by actively respiring organelles only depending upon their oxidative activity. Then, the cumulus cells were removed as described above, and the oocytes were washed 3 times in prewarmed PBS without BSA. The oocytes were fixed for $15 \mathrm{~min}$ at $37 \mathrm{C}$ using freshly prepared $2 \%$ paraformaldehyde in Hank's balanced salt solution. The M-7510 probe contains a thiolreactive chloromethyl moiety and can react with accessible thiol groups on peptides and proteins to form an aldehyde-fixable fluorescent conjugate that is well-retained after cell fixation over a period of six weeks. After fixation, the oocytes were washed 3 times in PBS, mounted on slides under coverslips, and stored in the refrigerator prior to evaluation by fluorescence microscopy.

An epifluorescence microscope (Jenalumar; Carl Zeiss, Jena, Germany) was used for all experiments. Emission wavelengths were separated by a $540 \mathrm{~nm}$ dichroic mirror followed by further filtering through a $570 \mathrm{~nm}$ long pass filter (red emission).
The mitochondrial aggregation pattern of the bovine oocytes was characterized by observation (up to $500 \times$ magnification) of labeled mitochondria that were oxidatively active. The aggregation patterns were mainly classified as fine (small pixels of fluorescence intensity throughout the cytoplasm), or aggregated (larger linear aggregations of fluorescence intensity).

The fluorescence intensity $(\mu \mathrm{A})$ was measured using a Photometry System P 100 (Nikon, Tokyo, Japan). Microscope adjustments and photomultiplier settings were kept constant for all experiments. Oocytes were positioned in the plane of focus, and the area of measurement was adapted to the size of the oocyte. The emission intensity/ oocyte data was reduced by compensation for the background fluorescence.

\section{Statistics}

The data was evaluated by Chi-square test, and all results with $\mathrm{P}<0.05$ were considered to be significant. Three replicates were performed in all experiments. Differences in the intensity of fluorescence of complex membrane-bound calcium-chlortetracycline were tested by ANOVA. Statistical analysis of the fluorescence intensity of mitochondria was conducted using the SAS System for Windows (release 8.02).

\section{Results}

\section{Experiment 1}

To determine the effect of rbST on the developmental competence of bovine oocytes, we compared the proportions of matured oocytes, i.e. metaphase II stage oocytes, cleaved embryos, and blastocysts after IVM in eight different treatment groups ( $\mathrm{n}=1,506$ oocytes). The data concerning rbST influence on bovine oocyte maturation in the different culture systems is shown in Tables 1 and 2. There were no differences in the percentages of oocytes reaching the metaphase II stage in all groups of experiments. As compared with the controls, supplementation with rbST or granulosa cells alone led to an increase in development to the blastocyst stage, but the highest level of blastocysts was observed after oocyte maturation with rbST and granulosa cells together $(\mathrm{P}<0.05)$. The positive effect of rbST on the developmental competence of oocytes did not depend on the type of serum used 
Table 1. Effect of rbST and granulosa cells (GC) on the developmental competence of oocytes matured in TCM 199 with FCS (CM 1) ( $n=792$ oocytes, 3 replicates)

\begin{tabular}{lccc}
\hline Culture system & Matured-M II \% (n) & Cleavage \% (n) & Developed to blastocyst \% (n) \\
\hline Control CM 1 & $75.8(75 / 99)$ & $35.9(32 / 89)^{\mathrm{a}}$ & $10.1(9 / 89)^{\mathrm{a}}$ \\
CM 1 + rbST & $77.7(80 / 103)$ & $48.5(47 / 97)^{\mathrm{a}}$ & $24.7(24 / 97)^{\mathrm{b}}$ \\
CM 1 + GC & $75.2(82 / 109)$ & $48.9(48 / 98)^{\mathrm{a}}$ & $25.5(25 / 98)^{\mathrm{b}}$ \\
CM 1 + rbST + GC & $78.4(80 / 102)$ & $69.5(66 / 95)^{\mathrm{b}}$ & $40.0(38 / 95)^{\mathrm{c}}$ \\
\hline
\end{tabular}

a:b, a:c, b:c $\mathrm{P}<0.05$ (within columns).

Table 2. Effect of rbST and granulosa cells (GC) on the developmental competence of oocytes matured in TCM 199 with ECS (CM 2) (n=722 oocytes, 3 replicates)

\begin{tabular}{lccc}
\hline Culture system & Matured-M II \% (n) & Cleavage \% (n) & Developed to blastocyst \% (n) \\
\hline Control CM 2 & $73.2(71 / 97)$ & $37.7(26 / 69)^{\mathrm{a}}$ & $11.6(8 / 69)^{\mathrm{a}}$ \\
CM 2 + rbST & $76.2(77 / 101)$ & $50.6(44 / 87)^{\mathrm{a}}$ & $20.7(18 / 87)^{\mathrm{a}}$ \\
CM 2 + GC & $79.6(78 / 98)$ & $47.9(45 / 94)^{\mathrm{a}}$ & $20.2(19 / 94)^{\mathrm{a}}$ \\
CM 2 + rbST + GC & $83.9(78 / 93)$ & $67.5(56 / 83)^{\mathrm{b}}$ & $36.1(30 / 83)^{\mathrm{b}}$ \\
\hline
\end{tabular}

a:b $\mathrm{P}<0.05$ (within columns).

during IVM.

\section{Experiment 2}

Since we did not obtain any significant differences in the quality of the culture systems in experiment 1 using FCS (CM 1) or ECS (CM 2), all subsequent investigations were done with only one culture system supplemented with FCS and $1 \times 10^{6}$ granulosa cells $/ \mathrm{ml}$.

Analysis of cytogenetic and morphological parameters revealed that rbST had an influence on subsequent embryo quality.

Figure 1 summarizes the data concerning the effect of rbST during IVM on subsequent embryo quality. The proportions of intact 2- to 4-cell embryos on day 2 and the proportion of intact morulae on day 5 were higher in the group of embryos originating from oocytes cultured with rbST $(\mathrm{P}<0.05)$.

\section{Experiment 3}

As in the second experiment, we used TCM $199+$ $10 \%$ FCS and $1 \times 10^{6}$ granulosa cells $/ \mathrm{ml}$ for maturation of oocytes in the presence or absence of $10 \mathrm{ng} / \mathrm{ml} \mathrm{rbST}$. For evaluation of the status of mitochondria and the level of $\left[\mathrm{Ca}^{2+}\right]_{\text {is, }}$ only intact oocytes with morphological signs of maturation (cumulus expansion, extrusion of a polar body) were used after IVM. The level of $\left[\mathrm{Ca}^{2+}\right]_{\text {is }}$ in oocytes, indicated by the fluorescence intensity of

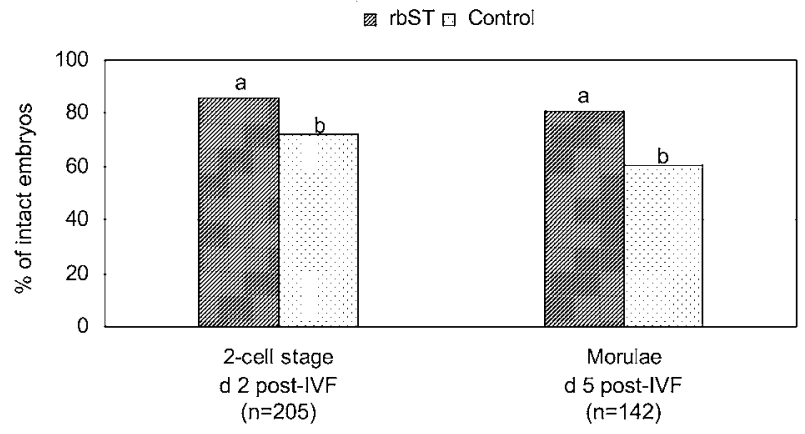

Fig 1. Embryo quality on days 2 and 5 after IVF of in vitromatured oocytes in TCM 199 with FCS (CM 1) + GC, with or without $10 \mathrm{ng} / \mathrm{ml} \mathrm{rbST}(\mathrm{n}=347$ embryos). ${ }^{\mathrm{a} b \mathrm{~b}} \mathrm{P}<0.05$.

calcium-CTC-complexes/oocyte, was decreased under the influence of rbST $(0.85 \mathrm{AU}<0.96 \mathrm{AU}$; $\mathrm{P}<0.05$ ) (Table 3).

The data in Table 4 demonstrates that the fluorescence intensity of the oocytes prelabeled by vital mitochondrial specific probe CMTM Ros and measured by fluorescence intensity at $570 \mathrm{~nm}$ emission/oocyte was significantly increased in oocytes matured in the presence of $10 \mathrm{ng} / \mathrm{ml} \mathrm{rbST}$ compared with those matured in the absence of rbSt $(309.2$ and $120 \mu \mathrm{A}$, respectively; $\mathrm{P}<0.05)$. In parallel, there was a slight tendency $(\mathrm{P}=0.1)$ for a higher proportion of oocytes with aggregated mitochondria after IVM with rbST. 
Table 3. Levels of intracellular stored calcium $\left(\mathrm{Ca}^{2+}\right)_{\text {is }}$ in bovine oocytes after IVM in TCM $199+$ FCS (CM 1) $+\mathrm{GC}$, with or without $10 \mathrm{ng} / \mathrm{ml} \mathrm{rbST}$

\begin{tabular}{lcc}
\hline $\begin{array}{c}\text { Treatment } \\
\text { group }\end{array}$ & No. of oocytes & $\begin{array}{c}\text { Fluorescence intensity } \\
\text { of the calcium-CTC } \\
\text { complexes in oocytes } \\
\text { (AU } \pm \text { SEM/oocyte) }\end{array}$ \\
\hline $\mathrm{CM} 1+\mathrm{GC}$ & 63 & $0.97 \pm 0.03^{\mathrm{a}}$ \\
$\mathrm{CM} 1+\mathrm{GC}+\mathrm{rbST}$ & 65 & $0.85 \pm 0.02^{\mathrm{b}}$ \\
\hline
\end{tabular}

a:b $\mathrm{P}<0.05$.

\section{Discussion}

It has been shown that growth hormones are involved in the processes of sexual differentiation, pubertal maturation, gonadal steroidogenesis, gametogenesis and ovulation [4]. Boland et al. [19] demonstrated that the effects of bST are related to the beneficial effect of IGF-I on the preovulatory follicle and on oocytes with a possible positive effect on subsequent CL function. Treatment of superovulated donor cows with GH at the time of insemination decreases the number of unfertilized oocytes and increases the percentage of transferable embryos. As was shown in an in vitro model, both GH and IGF-I stimulate embryonic development in cattle, and the effects of GH may likely involve IGFI-independent mechanisms [20].

Expression of GHR gene, the presence of the receptor in preimplantation bovine embryos, and the beneficial effect of GH on cleavage, blastocyst formation, and hatchability of embryos was shown by Izadyar et al. [5, 6]. The stimulatory effect of rbST during IVM on the development of bovine oocytes after IVF was also confirmed in our study. Moreover, we found that this effect is amplified in the presence of granulosa cells independent of the type of serum.

Bovine embryos derived in vitro are recognized as being of lower quality than those obtained following superovulation, artificial insemination, and non-surgical recovery [21]. In vitro-produced embryos have abnormalities in metabolism and a high incidence of chromosome abnormalities [2224]. The level of apoptosis is decreased by rbST in bovine blastocysts derived from in vitro-matured and fertilized oocytes [7]. In analysis of the morphology and chromatin status of in vitroproduced embryos on days 2 and 5 , rbST decreased
Table 4. Fluorescence intensity/oocyte and mitochondrial aggregation based on vital labeling of metabolic active mitochondria in bovine oocytes after IVM in TCM 199 + FCS (CM 1) + GC, with or without 10 $\mathrm{ng} / \mathrm{ml} \mathrm{rbST}$ ( $\mathrm{n}=73$ oocytes)

\begin{tabular}{lcc}
\hline $\begin{array}{c}\text { Treatment } \\
\text { group }\end{array}$ & $\begin{array}{c}\text { Fluorescence } \\
\text { intensity/oocyte } \\
(\mu \mathrm{A} \pm \mathrm{SEM})\end{array}$ & $\begin{array}{c}\text { Oocytes with } \\
\text { mitochondria in } \\
\text { aggregation \% (n) }\end{array}$ \\
\hline $\mathrm{CM} 1+\mathrm{GC}$ & $119.97 \pm 28.7^{\mathrm{a}}$ & $15.4(6 / 39)$ \\
$\mathrm{CM} 1+\mathrm{GC}+\mathrm{rbST}$ & $309.21 \pm 46.8^{\mathrm{b}}$ & $32.4(11 / 34)$ \\
\hline
\end{tabular}

a:b $\mathrm{P}<0.05$.

the proportion of embryos with morphological and chromatin abnormalities. In comparison with the experimental group, we found a higher proportion of degenerated embryos with bi- and multinuclear blastomeres, anuclear cells, pycnotic nuclei, and abnormal cytokinesis in the control group. Therefore, it is evident that the embryos obtained from in vitro-matured oocytes in the presence of rbST and granulosa cells had higher potential for continued development to blastocysts. This raises the question, which intracellular mechanisms could be involved in the rbST-derived effects on cytoplasmic oocyte maturation? Several studies have been carried out to study factors affecting the developmental competence of the oocyte [25].

In our study, we used two markers for evaluation of cytoplasmic maturation of bovine oocytes cocultured with granulosa cells; we compared the mitochondrial activity and the content of calcium in intracellular depots of oocytes matured in the presence or absence of rbST. The central role of mitochondria in metabolism and bioenergetics is well defined. It has been shown that the level of mitochondrial activity can be used for assessment of the functional status and quality of oocytes in pigs, cattle, and horses [10, 11, 26, 27]. In the present study, the oxidative activity of mitochondria in oocytes matured in the presence of rbST was significantly increased in comparison with the control group. The reason for the increase in fluorescence intensity of labeled mitochondria during maturation is likely an increase of respiratory activity to provide ATP for activation and preimplantation embryo development. Findings concerning increasing levels of fluorescence intensity of labeled mitochondria during porcine and bovine oocyte maturation [10, 28] positively correlate with the results of other 
authors $[11,29]$ who found increased levels of ATP content/oocyte during IVM.

Calcium is an important intracellular messenger, and calcium ions regulate many key intracellular events. It is known that calcium-dependent signalling pathways are involved in the regulation of mammalian oocyte meiotic maturation [30, 31]. A relationship between calcium stores and developmental competence has also been described for in vitro-matured bovine oocytes by He et al. [32], who used these parameters to evaluate differences between calf and cow oocytes. Thus, the plasma membrane $\mathrm{Ca}^{2+}$ currents of immature oocytes and intracellular $\mathrm{Ca}^{2+}$ stores in mature oocytes are good markers for the developmental potential of oocytes. Previously, we showed that normal oocytes have low levels of $\left[\mathrm{Ca}^{2+}\right]_{\text {is }}$ immediately after removal from follicles in comparison with oocytes with signs of degeneration [33]. Moreover, we suggested a relationship between the NADH concentration and calcium from intracellular stores in bovine oocytes. In the present study, we found that supplementation with rbST during IVM decreased the level of intracellular calcium stores in oocytes after maturation. An increase in mitochondrial activity and calcium exit from intracellular stores led to activation of metabolism in matured oocytes.

Izadyar et al. [8] showed that the stimulatory effect of growth hormone on in vitro maturation of bovine oocytes is exerted through cumulus cells and is not mediated by IGF-I. Addition of rbST during maturation of bovine oocytes decreased the level of pycnotic cells in cumulus cells [34]. The results of our study indicate a possible influence of bovine follicular granulosa cells on somatotropinrelated effects on the cytoplasmic maturation and developmental competence of oocytes in vitro.

In conclusion, the results of the present study clearly demonstrate that rbST supplementation together with follicular somatic cells (granulosa cells) has a beneficial effect on the cytoplasmic quality of bovine oocytes and their subsequent development to the blastocyst stage after IVF. In oocytes matured in the presence of rbST and somatic cells, increased levels of respiratory activity were associated with decreased levels of calcium from intracellular stores. Granulosa cells under the influence of somatotropin may produce a stimulatory substance(s) that promotes the potential of bovine oocytes for development to the blastocyst stages. Therefore, possible mechanisms of somatotropin-mediated effects on developmental competence of bovine oocytes are the subject of ongoing experiments.

\section{Acknowledgements}

This research was supported by the Federal Ministry of Food, Agriculture and Consumer Protection (BMELV, Germany).

\section{References}

1. Hansen PJ. Realizing the promise of IVF in cattle. Theriogenology 2006; 65: 119-125.

2. Yang X, Kubota C, Suzuki H, Taneja M, Bols PE, Presicce GA. Control of oocyte maturation in cows-biological factors. Theriogenology 1998; 49: 471-482.

3. Mendoza C, Ruiz-Requena R, Ortega E, Cremades N, Martinez F, Bernabeu R, Greco E, Tesarik J. Follicular fluid markers of oocyte developmental potential. Human Reprod 2002; 17: 1017-1022.

4. Hull KL, Harvey S. Growth Hormone roles in female reproduction. J Endocrinol 2001; 168: 1-23.

5. Izadyar F, Colenbrander B, Bevers MM. In vitro maturation of bovine oocytes in the presence of growth hormone accelerates nuclear maturation and promotes subsequent embryonic development. Mol Reprod Dev 1996; 45: 372-377.

6. Izadyar F, Hage WJ, Colenbrander B, Bevers MM.
The promotory effect of growth hormone on the developmental competence of in vitro matured bovine oocytes is due to improved cytoplasmic maturation. Mol Reprod Dev 1998; 49: 444-453.

7. Kolle S, Stojkovic M, Boie G, Wolf E, Sinowatz F. Growth hormone-related effects on apoptosis, mitosis, and expression of connexin 43 in bovine in vitro maturation cumulus-oocyte-complexes. Biol Reprod 2003; 68: 1584-1589.

8. Izadyar F, Van Tol HT, Colenbrander B, Bevers MM. Stimulatory effect of growth hormone on in vitro maturation of bovine oocytes is exerted through cumulus cells and not mediated by IGF-I. Mol Reprod Dev 1997; 47: 175-180.

9. Bavister B, Squirrell JM. Mitochondrial distribution and function in oocytes and early embryos. Hum Reprod 2000; 15 Suppl 2: 189-198.

10. Torner H, Brüssow KP, Alm H, Ratky J, Pöhland R, 
Tuchscherer A, Kanitz W. Mitochondrial aggregation patterns and activity in porcine oocytes and apoptosis in surrounding cumulus cells depends on the stage of pre-ovulatory maturation. Theriogenology 2004; 61: 1675-1689.

11. Stojkovic M, Machado SA, Stojkovic P, Zakhartchenko V, Hutzler P, Goncalves PB, Wolf E. Mitochondrial distribution and adenosine triphosphate content of bovine oocytes before and after in vitro maturation: correlation with morphological criteria and developmental capacity after in vitro fertilization and culture. Biol Reprod 2001; 64: 904-909.

12. Smaili SS, Hsu YT, Youle RJ, Russell JT. Mitochondria in $\mathrm{Ca}^{2+}$ signaling and apoptosis. Bioenerg Biomembr 2000; 32: 35-46.

13. Van Blerkom J, Davis $\mathbf{P}$, Mathwig V, Alexander S. Domains of high-polarized mitochondria may occur in mouse and human oocytes and early embryos. Hum Reprod 2002; 17: 393-406.

14. Ducibella T, Ukena T, Karnovsky M, Anderson E. Changes in cell surface and cytoplasmic organization during early embryo genesis in preimplantation mouse embryo. J Cell Biol 1977; 74: 153-157.

15. Mehlman L, Mikoshiba K, Kline D. Redistribution and increase in cortical inositol 1,4,5-trisphostphate receptors after meiotic maturation of the mouse oocyte. Dev Biol 1996; 180: 489-498.

16. Tarkowski AK. An air drying method for chromosomal preparation from mouse. Cytogenetic 1966; 1: 394-400.

17. Kuzmina TI, Lebedeva IY, Torner $\mathbf{H}$, Alm $\mathbf{H}$, Denisenko VY. Effects of prolactin on intracellular stored calcium in the course of bovine oocyte maturation in vitro. Theriogenology 1999; 51: 1363-1374.

18. Denisenko VY, Kuzmina TI, Shokin OV. Dependence of $\mathrm{Ca}^{2+}$ release from intracellular stores on NADH and FAD levels in fertilized and unfertilized bovine oocytes. Cytology 2005; 47: 704708. (in Russian)

19. Boland MP, Lonergan P, O'Gallaghan D. Effect of nutrition on endocrine parameters, ovarian physiology, and oocyte and embryo development. Theriogenology 2001; 55: 1323-1340.

20. Moreira F, Paula-Lopes FF, Hansen PJ, Badinga L, Thatcher WW. Effects of growth hormone and insulin-like growth factor-I on development of in vitro derived bovine embryos. Theriogenology 2002; 57: 895-907.

21. Enright BP, Lonergan P, Dinnyes A, Fair T, Ward FA, Yang $X$. Culture of in vitro produced bovine zygotes in vitro vs. in vivo: implications for early embryo development and quality. Theriogenology 2000; 54: 659-673.

22. Greve T, Xu KP, Callesen $\mathbf{H}$, Hyttel P. In vivo development of in vitro fertilized bovine oocytes matured in vivo vs. in vitro. J In Vitro Fert Embryo Transfer 1987; 4: 281-285.

23. Hyttel P, Viuff D, Fair T, Laurincik J, Thomsen PD, Callesen H, Vos PL, Hendriksen PJ, Dieleman SJ, Schellander K, Besenfelder U, Greve T. Ribosomal RNA gene expression and chromosome aberrations in bovine oocytes and preimplantation embryos. Reproduction 2001; 122: 21-30.

24. Khurana NK, Niemann H. Energy metabolism in preimplantation bovine embryos derived in vitro or in vivo. Biol Reprod 2000; 62: 847-856.

25. Sirard MA, Richard F, Blondin P, Robert C. Contribution of the oocyte to embryo quality. Theriogenology 2006; 65: 126-136.

26. Kuzmina TI, Galieva LD, Fedoskov ED, Ignatenko LD. Mitochondrial activity during the maturation of bovine oocytes in vitro. Reprod Dom Anim 1998; 33: Abstract 149.

27. Torner H, Alm H, Kanitz W, Goellnitz K, Becker F, Poehland R, Bruessow K-P, Tuchscherer A. Effect of initial cumulus morphology on meiotic dynamic and status of mitochondria in horse oocytes during IVM. Reprod Dom Anim 2007 (in press).

28. Tarazona AM, Rodriguez JI, Restrepo LF, OliveiraAngel M. Mitochondrial activity, distribution and segregation in bovine oocytes and in embryos produced in vitro. Reprod Dom Anim 2006; 41: 5-11.

29. Brevini TA, Vassena R, Francisci C, Gandolfi F. Role of adenosine triphosphate, active mitochondria, and microtubules in the acquisition of developmental competence of partheno-genetically activated pig oocytes. Biol Reprod 2005; 72: 1218-1223.

30. Carrol J, Jones KT, Whittingham DC. $\mathrm{Ca}^{2+}$ release and the development of $\mathrm{Ca}^{2+}$ release mechanisms during oocyte maturation: a prelude to fertilization. Rev Reprod 1996; 1: 137-143.

31. Herbert M, Gillespie JI, Murdoch AP. Development of calcium signalling mechanisms during maturation of human oocytes. Mol Human Reprod 1997; 3: 965-973.

32. He CL, Damiani P, Parys JB, Fissore RA. Calcium, calcium release receptors, and meiotic resumption in bovine oocytes Biol Reprod 1997; 57: 1245-1255.

33. Kuzmina TI, Maleshev AY. Hyper accumulation of membrane-bound $\mathrm{Ca}^{2+}$ in the bovine oocytes during expansion and dissolution of the cumulus-oocytes complex. Bulletin VNIIRGG 1991; 129: 3-7 (in Russian).

34. Kuzmina TI, Shelouchina TV, Neckrasova NN. Effect of somatotropin on nuclear status and morphology of bovine cumulus oocytes complexes. In: $50^{\text {th }}$ Annual Meeting of the European Association for Animal Production, 1999; Zurich, Switzerland. Abstract 164. 